(c) 2018 - ISSN 1807-2577

\title{
The effect of a $3 \%$ hydroxyapatite paste prophylaxis after different root-scaling procedures in periodontics
}

\author{
Efeito da profilaxia com pasta de hidroxiapatita 3\% após diferentes \\ procedimentos de raspagem radicular na periodontia
}

\author{
Luis Gustavo Gonzalez OSUNA ${ }^{\mathrm{a}}$ (1), Guilherme José Pimentel Lopes de OLIVEIRA ${ }^{\mathrm{a}}$ (D),

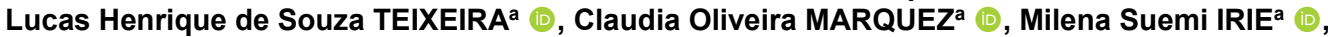 \\ Priscilla Barbosa Ferreira SOARES ${ }^{a *}$ (1) \\ a UFU - Universidade de Uberlândia, Faculdade de Odontologia, Departamento Periodontia e Implantodontia, \\ Uberlândia, MG, Brasil
}

\begin{abstract}
How to cite: Osuna LGG, Oliveira GJPL, Teixeira LHS, Marquez CO, Irie MS, Soares PBF. The effect of a 3\% hydroxyapatite paste prophylaxis after different root-scaling procedures in periodontics. Rev Odontol UNESP. 2019;48:e20190040. https://doi.org/10.1590/1807-2577.04019
\end{abstract}

\begin{abstract}
Resumo
Introdução: Procedimentos de raspagem na superfície radicular aumentam a rugosidade superficial durante a instrumentação. 0 uso de pasta profilática pode reduzir a rugosidade. Objetivo: Este estudo avaliou a influência da profilaxia com pasta na rugosidade superficial da dentina radicular após instrumentação manual (IH), ultrassom (US) e instrumentos rotatórios (IR) aplicados em superfícies radiculares. Material e método: Cinquenta raízes bovinas foram preparadas e divididas aleatoriamente em 10 grupos $(\mathrm{n}=5)$ nos quais a instrumentação com HI, US ou RI foi realizada com ou sem profilaxia usando pasta convencional ou hidroxiapatita a $3 \%$; adicionalmente, um grupo controle sem tratamento foi incluído. As rugosidades de Ra e Rz foram medidas por um perfilômetro. Os aspectos morfológicos das superfícies radiculares foram analisados qualitativamente por microscopia eletrônica de varredura (MEV). Os dados foram analisados por meio de ANOVA de dois fatores, seguido pelo teste de Tukey $(\alpha=0,05)$. Resultado: 0 método de raspagem e o procedimento de profilaxia influenciaram significativamente $(p<0,05)$ a rugosidade da superfície radicular. 0 tratamento com US e a profilaxia com pasta de hidroxiapatita ao $3 \%$ resultaram em menores valores de $\operatorname{Ra}(0,14 \mu \mathrm{m} \pm 0,02 \mu \mathrm{m})$ e $\operatorname{Rz}(0,89 \mu \mathrm{m} \pm 0,18 \mu \mathrm{m})$ em relação aos demais grupos. A análise por MEV mostrou superfícies mais lisas e mais homogêneas nos grupos com profilaxia em comparação aos grupos sem profilaxia. Não houve diferenças substanciais entre os resultados da aplicação das diferentes pastas. Conclusão: 0 procedimento de profilaxia realizado com a pasta experimental contendo $3 \%$ de hidroxiapatita reduziu a rugosidade das superfícies radiculares tratadas com HI, US e RI no mesmo nível da pasta profilática convencional.
\end{abstract}

Descritores: Raspagem radicular; biofilme; profilaxia dental.

\begin{abstract}
Introduction: Root-scaling procedures on the root surface show to increase root surface roughness during instrumentation. The use of a prophylactic paste reduces the roughness. Objetive: This study evaluated the influence of prophylaxis paste on the surface roughness of root dentin after hand instruments (HI), ultrasonic scalers (US) and rotational instruments (RI) were applied to root surfaces. Material and method: Fifty bovine roots were prepared and randomly divided into 10 groups $(n=5)$ in which instrumentation with HI, US, or RI was carried out with or without prophylaxis using either conventional or 3\% hydroxyapatite paste; additionally, a control group without treatment was included. The Ra and Rz roughness values were measured using a perfilometer. The morphological aspects of the root surfaces were analysed qualitatively by scanning electron microscopy (SEM). Data were analysed using two-way ANOVA followed by Tukey's test $(\alpha=0.05)$. Result: The scaling method and the prophylaxis procedure significantly influenced $(\mathrm{p}<0.05)$ root surface roughness. Treatment with US and prophylaxis with $3 \%$ hydroxyapatite
\end{abstract}


paste resulted in lower values of $\operatorname{Ra}(0.14 \mu \mathrm{m} \pm 0.02 \mu \mathrm{m})$ and $\operatorname{Rz}(0.89 \mu \mathrm{m} \pm 0.18 \mu \mathrm{m})$ compared to the other groups. SEM analysis showed smoother and more homogeneous surfaces in the groups with prophylaxis compared to the groups without prophylaxis. There were no substantial differences between the results of applying different pastes. Conclusion: The prophylaxis procedure performed with the experimental paste containing $3 \%$ hydroxyapatite reduced the roughness of root surfaces treated with HI, US and RI at the same level as the conventional prophylactic paste.

Descriptors: Root scaling; biofilm; dental prophylaxis.

\section{INTRODUCTION}

Periodontal disease is a group of conditions characterized by gingival inflammation and bone resorption. It is promoted by the host inflammatory response against the microbial challenge induced by bacterial products presented in dental biofilms ${ }^{1}$. The treatment of periodontitis has been traditionally performed to remove biofilm and calculus deposits ${ }^{2}$. Indeed, non-surgical periodontal therapy is still considered the first approach to control periodontal disease since this therapy has been shown to reduce the bacterial load in the periodontal pocket, thereby causing an improvement in periodontal clinical parameters ${ }^{2,3}$.

Hand instruments (HI) are the most used tools for non-surgical periodontal treatment, and they have been shown to be efficient in the removal of biofilm and calculus deposits ${ }^{4}$. However, scaling with $\mathrm{HI}$ has been shown to present some important limitations in regards to accessing the furcation's lesions, root concavities and sulci, and deep pockets 2,5 . Therefore, complete removal of the biofilm and calculus deposits is not common ${ }^{2,5}$. Furthermore, the efficacy of scaling with $\mathrm{HI}$ is highly dependent on the operator's experience and skill6. These limitations demonstrate that the use of alternative tools for scaling performed during non-surgical periodontal therapy is required ${ }^{5,7}$.

Among the alternative tools proposed to be used in scaling procedures, ultrasonic scalers (US) and rotatory instruments (RI) deserve attention, since these instruments have been shown to increase the efficiency of the scaling procedure by removing similar or larger quantities of biofilm and calculus deposits in a reduced time compared to $\mathrm{HI}^{8,9}$. In fact, the improvement of clinical outcomes induced by the scaling performed with US and RI is equivalent to that of scaling performed with $\mathrm{HI}^{9,10}$. Moreover, the use of these alternative instruments can improve the access to periodontal instrumentation, thereby making the scaling procedure easier to perform ${ }^{11}$.

The use of HI, US and RI on the root surface has been shown to increase root surface roughness due to the formation of irregularities and sulcus during instrumentation ${ }^{12,13}$. The augmentation of root surface roughness after the scaling procedures can be implicated in increased biofilm adhesion in the supragingival environment and improvement in periodontal regeneration in the subgingival environment ${ }^{14,15}$. In any case, the polishing of the root surfaces exposed to the oral environment should always be performed to reduce the niches for biofilm accumulation and to enhance the performance of mechanical biofilm control by the patient ${ }^{16,17}$.

A myriad of prophylactic pastes has been indicated for polishing procedures after periodontal treatment ${ }^{17}$. However, prophylactic pastes have no effect on the augmentation of dentin strength. The use of a prophylactic paste can reduce root surface roughness associated with the improvement in dentin microhardness, which can prevent erosion caused by brushing the root surfaces that are exposed after periodontal treatment. The use of compounds with hydroxyapatite has been shown to improve dentin microhardness and occlude dentin tubules ${ }^{18,19}$. Accordingly, the use of the new prophylactic paste with $3 \%$ hydroxyapatite could be a good option for polishing procedures. The aim of this study was to evaluate the effect of the $3 \%$ hydroxyapatite prophylactic paste on root surfaces previously scaled by HI, US, and RI compared to the roughness of the root surfaces polished with a conventional prophylactic paste. 


\section{MATERIAL AND METHOD}

\section{Sample Preparation}

Fifty extracted bovine incisors were selected for this study. The teeth were stored at $37^{\circ} \mathrm{C}$ in distilled water that was changed weekly. The crown and root portion were separated at the enamel-cementum junction with a double-faced diamond disk (KG Sorensen, Barueri, SP, Brazil) in a low-speed handpiece (KaVo do Brasil Ltda, Joinville, SC, Brazil) under copious water spray. Then, the root was mounted and adapted individually with light pressure on a wax plate (Wilson Polidental, São Paulo, SP, Brazil). The root was embedded in self-polymerizable resin (Jet Clássico, São Paulo, SP, Brazil)) in plastic cylinders with a diameter of $20.0 \mathrm{~mm}$ (Tigre, São Paulo, Brazil). The surface to be analysed was finished using 600-, 800-, 1200- and 2000-grit silicon-carbide papers (Norton, Campinas, SP, Brazil) and polished with metallographic diamond pastes $(6,3,1,1 / 4 \mu \mathrm{m}$; Arotec, São Paulo, SP, Brazil). The samples were washed 3 times for 10 minutes in each section in an ultrasound bath (Cristofoli, Campo Mourão, Paraná, Brazil) with absolute alcohol to remove debris.

\section{Groups}

The samples were randomly divided into 10 groups according to the type of treatment applied to the root surfaces ( $\mathrm{n}=5$ ): $\mathrm{C}$ (control group): no treatment; HI: scaling with hand instruments (Gracey curettes 5/6; Hu-Friedy, Chicago, Illinois, USA), totalling 15 movements in an apical-coronal direction; HI/PP: scaling with HI, totalling 15 movements in an apical-coronal direction followed by prophylaxis with a fine prophylactic paste (Herjos-F; Vigodent S.A., Rio de Janeiro, RJ, Brazil) using a rubber cup coupled with a low-speed rotation device under constant irrigation for 15 seconds; HI/EP: scaling with HI (Gracey curettes 5/6; Hu-Friedy, Chicago, Illinois, USA), totalling 15 movements in an apicalcoronal direction followed by prophylaxis with an experimental paste with $3 \%$ hydroxyapatite (Bianco; Uberlândia, MG, Brazil) using a rubber cup coupled with a low-speed rotation device under constant irrigation for 15 seconds; US: scaling with a US (Jet Sonic Total; Gnatus, Ribeirão Preto, SP, Brazil), totalling 15 instrumentation cycles in the apical-coronal direction; US/PP: scaling with a US, totalling 15 instrumentation cycles in the apical-coronal direction followed by prophylaxis with a fine prophylactic paste using a rubber cup coupled with a low-speed rotation device under constant irrigation for 15 seconds; US/EP: scaling with a US, totalling 15 instrumentation cycles in the apicalcoronal direction followed by prophylaxis with an experimental paste with $3 \%$ hydroxyapatite using a rubber cup coupled with low-speed rotation device under constant irrigation for 15 seconds; RI: scaling with RI (740F; KG Sorensen, Cotia, SP, Brazil) coupled with a low-speed rotation device totalling 15 instrumentation cycles in a mesiodistal direction; RI/PP: scaling with RI coupled with a low-speed rotation device totalling 15 instrumentation cycles in a mesiodistal direction followed by prophylaxis with a fine prophylactic paste using a rubber cup coupled with a low-speed rotation device under constant irrigation for 15 seconds; RI/EP: scaling with RI coupled with a low-speed rotation device, totalling 15 instrumentation cycles in a mesiodistal direction followed by prophylaxis with an experimental paste with 3\% hydroxyapatite using a rubber cup coupled with a low-speed rotation device under constant irrigation for 15 seconds. An area of $5 \times 5 \mathrm{~mm}^{2}$ was delimited on the exposed root surface as the area to be instrumented. This area was used for the roughness and morphological analysis of the root surfaces. The samples were prepared by the same operator (LGGO). 


\section{Determination of the Root Surface Roughness}

After the treatments were applied to the root surfaces, the area previously delimited was used to determine the root surface roughness by a perfilometer (Surftest SJ-201P; Mitutoyo Corporation, Kawasaki, Kanagawa, Japan). Three readings in different directions for each specimen were performed, and the average was calculated; this value was considered the roughness value of each sample. The measurement was performed with a 0.25 -mm cut-off value and $1.25-\mathrm{mm}$ measurement length, with measuring speed of $1 \mathrm{~mm} / \mathrm{s}$, covering the distance of $3 \mathrm{~mm}$. In this study, two roughness parameters were used: mean roughness (Ra), the arithmetic mean of the recorded peaks and valleys; and mean roughness depth (Rz), the maximum distance between the greatest peak and the greatest valley in the measuring path. The perfilometer was positioned so that the height of the reading tip was adapted to the previous map of each sample.

\section{Scanning Electronic Microscopy (SEM) Analysis}

The morphological features of the root surfaces were analyzed using SEM. Five samples from each group were sectioned using a double-faced diamond disc (KG Sorensen, Cotia, SP, Brazil) at low speed and under air-water spray cooling at a distance of $1 \mathrm{~mm}$ from the edges of the instrumentation area. The samples were cleaned in an ultrasonic device (Cristofoli, Campo Mourão, Paraná, Brazil) with distilled water for 30 minutes to remove the debris remnants and were dehydrated in alcohol at concentrations of $50^{\circ}, 70^{\circ}$ and $95^{\circ}$ for $10 \mathrm{~min}$ each and in absolute alcohol for $30 \mathrm{~min}$. After storage in an oven receptacle containing silica for $8 \mathrm{~h}$ to remove moisture, the specimens were mounted on an aluminium stub (one stub per group), sputtercoated with a thin layer of gold, and examined with an LEO 435 VP scanning electron microscope (Carl-Zeiss NTS GmbH, Oberkochen, Germany). The SEM photomicrographs at $\times 500$ magnification were scored blindly and independently by five investigators using roughness and loss of tooth substance index ${ }^{20}$ (Table 1). This index was used to qualitatively score the morphology of the root surface produced by each instrument with or without prophylaxis.

Table 1. Roughness and loss of tooth substance index (Meyer; $\mathrm{Lie}^{20}$ )

\begin{tabular}{cl}
\hline & Score Feature \\
1 & Smooth and even root surface without marks from instrumentation and with no loss of tooth substance \\
2 & $\begin{array}{l}\text { Definitely corrugated local areas where the cementum may be completely removed, although most of } \\
\text { the cementum is still present } \\
3\end{array}$ \\
Considerable loss of tooth substance with instrumentation marks into the dentin. The cementum is \\
completely removed in large areas or has a considerable number of lesions from the instrumentation.
\end{tabular}

\section{Statistical Analysis}

The Ra, Rz and score data were tested for normal distribution (Shapiro-Wilk test) and equality of variances (Levene's test). The two-way analysis of variance followed by Tukey's test were used for comparison among experimental groups and between each experimental group and the control group. The significance level was set at $5 \%$, and all analyses were carried out with the statistical package Sigma Plot version 13.1 (Systat Software Inc, San Jose, CA, USA). 


\section{RESULT}

\section{Roughness}

A two-way ANOVA revealed that prophylaxis method, scaling method, and interaction between both factors significantly influenced $(\mathrm{p} \leq 0.05)$ the Ra and $\mathrm{Rz}$ values. When scaling was conducted using RI, higher Ra values were found in comparison with HI or US. When performed after any treatment, prophylaxis using paste with 3\% hydroxyapatite or fine prophylactic paste resulted in significantly lower Ra values than those in groups that did not receive prophylaxis. When scaling was performed using US followed by prophylaxis with the $3 \%$ hydroxyapatite experimental paste, the lowest Ra values were found. When comparing each experimental group to the control group, Dunnet's test showed that US, RI, RI/PP and RI/EP had higher Ra values than those in the control group (Table 2). The lowest Rz value was found when US and prophylaxis using paste with $3 \%$ hydroxyapatite were performed.

Table 2. Mean if the Ra and Rz values $(\mu \mathrm{m})$ and standard deviations of all the groups $(n=5)$

\begin{tabular}{|c|c|c|c|c|c|}
\hline & \multirow{2}{*}{ Prophylaxis Methods } & \multicolumn{3}{|c|}{ Scaling Methods } & \multirow{2}{*}{ Control } \\
\hline & & HI & US & RI & \\
\hline \multirow{2}{*}{$\operatorname{Ra}(\mu \mathrm{m})$} & Without prophylaxis & $0.42 \pm 0.16 \mathrm{Ab}$ & $0.62 \pm 0.30 \mathrm{Ab}^{* * *}$ & $2.10 \pm 0.43 \mathrm{Bc}^{* * *}$ & \multirow[t]{2}{*}{$0.09 \pm 0.05$} \\
\hline & $\begin{array}{l}\text { Prophylaxis with a } \\
\text { hydroxyapatite } 3 \% \text { paste }\end{array}$ & $0.30 \pm 0.21$ Аа & $0.14 \pm 0.02 \mathrm{Аа}$ & $1.18 \pm 0.07 \mathrm{Ba}^{* * *}$ & \\
\hline \multirow{3}{*}{$\operatorname{Rz}(\mu \mathrm{m})$} & Without prophylaxis & $2.29 \pm 0.96 \mathrm{Bb}^{* * *}$ & $1.64 \pm 0.40 \mathrm{Ab}$ & $1.71 \pm 0.42$ Аа & \multirow[t]{3}{*}{$0.82 \pm 0.49$} \\
\hline & $\begin{array}{l}\text { Prophylaxis with a fine } \\
\text { prophylactic paste }\end{array}$ & $1.53 \pm 0.35$ Аа & $1.42 \pm 0.36 \mathrm{Ab}$ & $1.80 \pm 0.59 \mathrm{Aa}^{*}$ & \\
\hline & $\begin{array}{l}\text { Prophylaxis with a } \\
\text { hydroxyapatite } 3 \% \text { paste }\end{array}$ & $1.55 \pm 0.65 \mathrm{Ba}$ & $0.89 \pm 0.18$ Аа & $1.83 \pm 0.30 \mathrm{Ba}^{*}$ & \\
\hline
\end{tabular}

Different letters indicate significant differences for Tukey's honestly significant difference test $(p<0.05)$. Uppercase letters compare scaling methods (in rows). Lowercase letters compare prophylaxis methods in each impact scaling methods (in columns). ${ }^{*} \mathrm{p}<0.05$; ${ }^{* * *} \mathrm{p}<0.001$ Groups with higher roughness values than the control group - Two-way ANOVA complemented by Tukey's test.

After prophylaxis with both pastes in the HI and US groups, the Rz values were significantly reduced compared to those in the groups with no prophylaxis. When RI was used for scaling, the $\mathrm{Rz}$ values were not influenced by prophylaxis method. When comparing each experimental group to the control group, Dunnet's test showed that HI, RI/PP and RI/EP had higher Rz values than those in the control group (Table 2).

\section{SEM Analysis}

The two-way ANOVA revealed that prophylaxis method, scaling method, and the interaction between both factors significantly influenced $(p \leq 0.05)$ the morphological features of the root surfaces. In general, when prophylaxis was performed with any paste, the root surface became smoother than the surfaces that were not submitted to prophylaxis (Figure 1). The treatment of the root surface using both US and prophylaxis using paste with 3\% hydroxyapatite (Figure 1G) presented the highest degree of smoothness. Performing prophylaxis after HI (Figures 1C and 1D) or US (Figures $1 \mathrm{~F}$ and $1 \mathrm{G}$ ) with either paste induced a smoother surface than in the groups with no prophylaxis (Figures 1B and 1E). Prophylaxis influenced the morphological features of the root surfaces treated by RI (Figures $1 \mathrm{H}-1 \mathrm{~J}$ ). When comparing each experimental group to the control group (Figure 1A), Dunnet's test showed that only RI/EP (Figure 1J) resulted in similar roughness scores to that in the control group (Table 3); all other groups had significantly higher scores than the control group. 
Table 3. Mean of the roughness and loss of tooth substance index values and standard deviations of all the groups $(n=5)$

\begin{tabular}{ccccc}
\hline \multirow{2}{*}{ Prophylaxis Methods } & \multicolumn{3}{c}{ Scaling Methods } & \multirow{2}{*}{ Control } \\
\cline { 2 - 4 } & HI & US & RI & \\
\hline Without prophylaxis & $1.1 \pm 0.8 \mathrm{Aa}^{* * *}$ & $2.5 \pm 0.5^{\mathrm{Bb}^{* * *}}$ & $2.6 \pm 0 . \mathrm{Bc}^{* * *}$ & $0.0 \pm 0.0$ \\
Prophylaxis with a fine prophylactic paste & $0.8 \pm 0.4 \mathrm{Aa}^{* *}$ & $0.6 \pm 0.5 \mathrm{Aa}^{* * *}$ & $1.1 \pm 0.6^{\mathrm{Aa} * *}$ & \\
$\begin{array}{c}\text { Prophylaxis with a hydroxyapatite 3\% } \\
\text { paste }\end{array}$ & $0.7 \pm 0.5 \mathrm{Aa}^{* *}$ & $0.8 \pm 0.4 \mathrm{Aa}^{* * *}$ & $0.5 \pm 0.3 \mathrm{Aa}$ & \\
\hline
\end{tabular}

Different letters indicate significant differences for Tukey's honestly significant difference test $(\mathrm{P}<0.05)$. Uppercase letters compare scaling methods (in rows). Lowercase letters compare prophylaxis methods in each impact scaling methods (in columns). ${ }^{* *} \mathrm{p}<0.01 ;{ }^{* * *} \mathrm{p}<0.001$ Groups with higher roughness and loss of tooth substance index values than the control group - Two-way ANOVA complemented by Tukey's test.

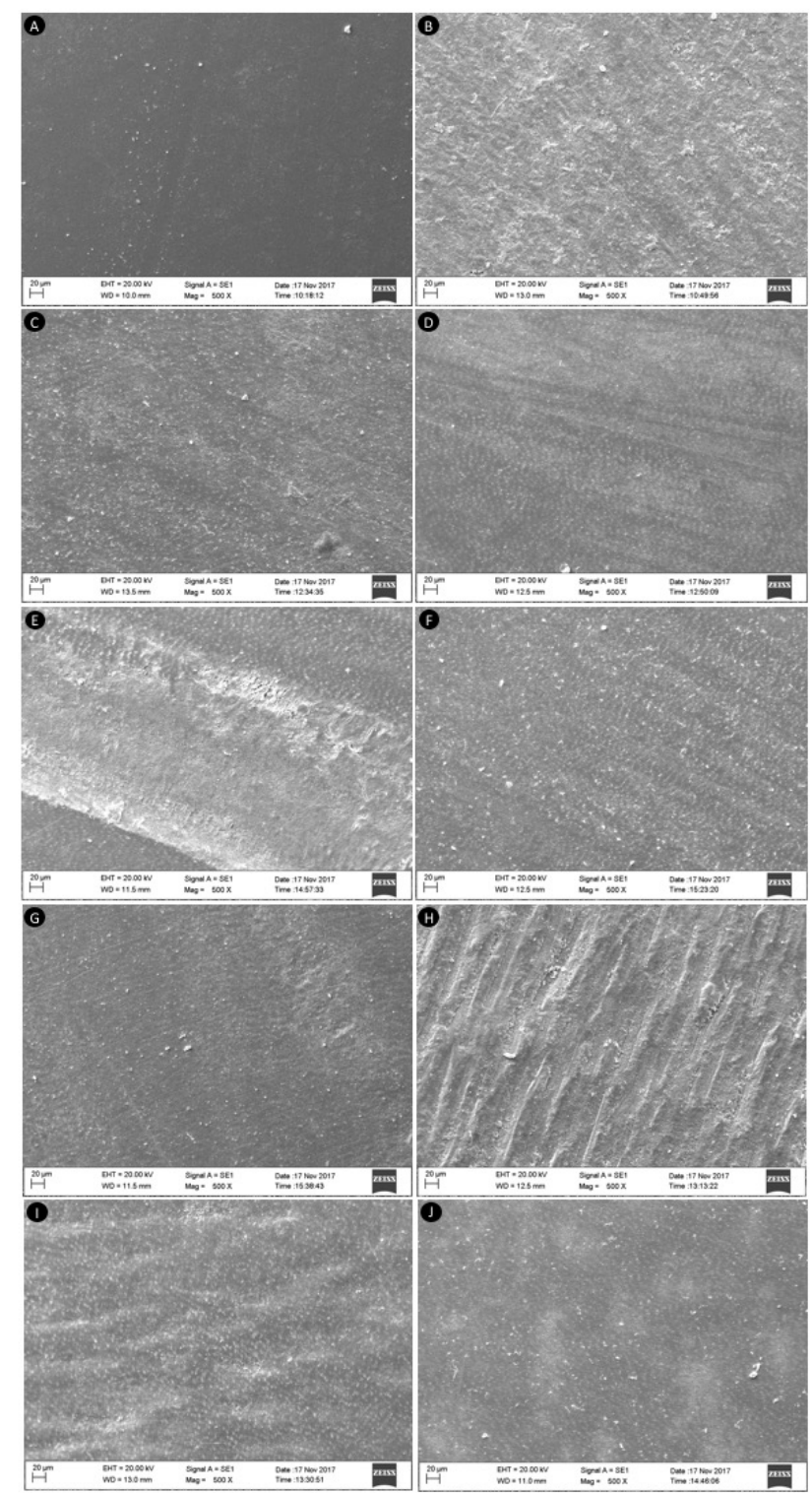

Figure 1. Photomicrograph at $\times 500$ magnification showing the morphology of root surface as assessed via scanning electron microscopy (SEM) in: (A) Control group; (B) Scaling with $\mathrm{HI}$; (C) Scaling with $\mathrm{HI}$ with prophylaxis with a fine prophylactic paste; (D) Scaling with $\mathrm{HI}$ with prophylaxis with a hydroxyapatite $3 \%$ paste; (E) Scaling with a US; (F) Scaling with a US with prophylaxis with a fine prophylactic paste; (G) Scaling with a US with prophylaxis with a hydroxyapatite $3 \%$ paste; $(\mathrm{H})$ Scaling with $\mathrm{RI}$; (I) Scaling with RI with prophylaxis with a fine prophylactic paste; $(\mathrm{J})$ Scaling with $\mathrm{RI}$ with prophylaxis with a hydroxyapatite $3 \%$ paste. 


\section{DISCUSSION}

Scaling procedures performed in non-surgical periodontal treatment have the objective of removing microbial deposits, and when performed efficiently, are associated with the formation of a root surface that reduces the possibility of new accumulation of these deposits ${ }^{2}$. Thus, it has been suggested that after non-surgical periodontal treatment, the root surface should ideally be smooth, hard and polished ${ }^{21}$. Although the scaling procedures performed with HI have been considered the standard treatment for periodontal disease, this procedure is difficult to perform, and the degree of the root surface roughness promoted by this treatment indicates that the root surfaces should be polished after the scaling 16,17 , as confirmed by this study. Additional tools for non-surgical periodontal treatment, such as US and RI, have been proposed to facilitate the scaling procedure ${ }^{8,12}$; however, this study showed that the use of these alternatives does not eliminate the necessity to polish the root surfaces.

Perfilometer analysis is a two-dimensional measurement that provides reliable data for characterizing root surfaces roughness after debridement ${ }^{16}$. The roughness data showed that the RI promoted higher average roughness values (Ra); however, HI promoted higher partial roughness values (Rz). The average roughness is the arithmetic average of the roughness of the whole surface, and therefore, it better estimates the outcome for the entire surface ${ }^{22}$. Indeed, the SEM images of this study showed that surfaces treated with RI and US had a more irregular appearance than the untreated surfaces or the surfaces scaled with HI instruments. Although the $\mathrm{Rz}$ roughness was paradoxically higher after instrumentation with $\mathrm{HI}$, this roughness determined the sum of the values of the greatest distance between the top and the valley of a surface; parameters such as the wear of the treated surface strongly impact this value ${ }^{23}$, which may indicate that there is a greater removal of dentin tissue after instrumentation with HI compared to the use of US and IR, a fact already shown in previous studies 24,25 .

The $\mathrm{Ra}$ and $\mathrm{Rz}$ roughness were reduced on all root surfaces that were polished with both prophylactic pastes. However, the root surfaces treated with the RI instruments and polished with the prophylactic pastes had higher roughness than non-instrumented surfaces, suggesting that the time needed for a good polishing of these surfaces is greater than that for instrumentation with US and HI. In addition, the experimental prophylactic paste with $3 \%$ hydroxyapatite reduced the root surface roughness at the same level as that obtained with the conventional prophylactic paste, which demonstrates that experimental paste presents a good potential for clinical use. The use of hydroxyapatite-based products has been shown to increase dentin microhardness ${ }^{17,18}$, and this effect may be important in preventing abrasion defects that may occur on root surfaces exposed to the oral environment ${ }^{19}$. However, this hypothesis still requires further investigation.

The best combination of treatment found in this study was US in addition to polishing with the prophylactic 3\% hydroxyapatite paste. The application of US on the root surfaces has been shown to produce a reduced or equal root surface roughness than that produced by $\mathrm{HI}^{8,25}$, which may suggest that the polishing procedure can be applied for shorter times than for surfaces treated with the other tools. In addition, the US treatment has also been shown to remove less dentin tissue compared to other instruments ${ }^{25}$, which may also facilitate obtaining a more polished surface and reducing the possibility of dentin hypersensitivity after scaling since the superficial dentin layers present fewer dentinal tubules and a reduction in tubule diameter 25 .

This study has some limitations that limit data extrapolation to clinical practice. The effect of prophylaxis procedure is mostly restricted to the enamel and the first millimeters of coronal third of the root surface. Therefore, caution should be taken when comparing the present results to enamel roughness analysis, since dentin root samples were used. It has been demonstrated ${ }^{17}$ that composite and dentin surfaces were more affected by prophylaxis than enamel and porcelain surfaces. Previous studies have shown that compounds with hydroxyapatite increase the hardness of dentin and dental enamel 17,18 , however, the real impact of the application of prophylaxis with an experimental paste containing $3 \%$ hydroxyapatite on dentin hardness was 
not measured. In addition, important information such as the effect of prophylactic paste with $3 \%$ hydroxyapatite on the resistance of the treated root surfaces to brush-induced wear and the duration of brushing cycles of these surfaces is uncertain. Future studies are necessary to obtain this information.

The polishing procedure performed with the experimental paste containing 3\% hydroxyapatite reduced the roughness of the root surfaces instrumented with HI, US and RI at the same level as that obtained with the conventional prophylactic paste. In addition, the treatment of the root surface with US and the subsequent polishing with the prophylactic paste containing $3 \%$ hydroxyapatite was the treatment that presented the best pattern of reduction of roughness and was associated with improvement in the morphological pattern of treated root surfaces.

\section{ACKNOWLEDGEMENTS}

This study has been supported by a grant from Foundation for Research Support of Minas Gerais (FAPEMIG - Minas Gerais, Brazil) and National Council of Scientific Research and Development (CNPq, Brazil). This study was financed in part by the Coordenação de Aperfeiçoamento de Pessoal de Nível Superior - Brasil (CAPES) - Finace Code 001. The authors also thank the Scanning Electron Microscopy Laboratory of the School of Chemical Engineering of Federal University of Uberlandia (FEQUI-UFU) for the SEM analysis.

\section{REFERENCES}

1. Bosshardt DD. The periodontal pocket: pathogenesis, histopathology and consequences. Periodontol 2000. 2018 Feb;76(1):43-50. http://dx.doi.org/10.1111/prd.12153. PMid:29194796.

2. Graziani F, Karapetsa D, Alonso B, Herrera D. Nonsurgical and surgical treatment of periodontitis: how many options for one disease? Periodontology 2000. Periodontol 2000. 2017 Oct;75(1):152-88. http://dx.doi.org/10.1111/prd.12201. PMid:28758300.

3. Lindhe J, Westfelt E, Nyman S, Socransky SS, Haffajee AD. Long-term effect of surgical/non-surgical treatment of periodontal disease. J Clin Periodontol. 1984 Aug;11(7):448-58. http://dx.doi.org/10.1111/j.1600-051X.1984.tb01344.x. PMid:6378986.

4. Braun A, Krause F, Frentzen M, Jepsen S. Efficiency of subgingival calculus removal with the Vector ${ }^{\mathrm{TM}}$ system compared to ultrasonic scaling and hand instrumentation in vitro. J Periodontal Res. 2005 Feb;40(1):48-52. http://dx.doi.org/10.1111/j.1600-0765.2004.00768.x. PMid:15613079.

5. Cobb CM. Lasers and the treatment of periodontitis: the essence and the noise. Periodontol 2000. 2017 Oct;75(1):205-95. http://dx.doi.org/10.1111/prd.12137. PMid:28758295.

6. Kozlovsky A, Rapaport A, Artzi Z. Influence of operator skill level on the clinical outcome of nonsurgical periodontal treatment: a retrospective study. Clin Oral Investig. 2018 Nov;22(8):2927-32. http://dx.doi.org/10.1007/s00784-018-2380-7. PMid:29450739.

7. de Oliveira GJ, Pavone C, Sampaio JE, Marcantonio RA. Influence of the angle of irradiation of the Er,Cr:YSGG laser on the morphology, attachment of blood components, roughness, and root wear: In vitro study. Lasers Surg Med. 2010 Nov;42(9):683-91. http://dx.doi.org/10.1002/lsm.20973. PMid:20976808.

8. Maritato M, Orazi L, Laurito D, Formisano G, Serra E, Lollobrigida M, et al. Root surface alterations following manual and mechanical scaling: a comparative study. Int J Dent Hyg. 2018 Nov;16(4):553-8. http://dx.doi.org/10.1111/idh.12349. PMid:29797806.

9. Türktekin F, Buduneli N, Lappin DF, Türk T, Buduneli E. Diamond burs versus curettes in root planing: a randomized clinical trial. Aust Dent J. 2018 Jun;63(2):242-52. http://dx.doi.org/10.1111/adj.12602. PMid:29432640. 
10. Obeid PR, D'Hoore W, Bercy P. Comparative clinical responses related to the use of various periodontal instrumentation. J Clin Periodontol. 2004 Mar;31(3):193-9. http://dx.doi.org/10.1111/j.03036979.2004.00467.x. PMid:15016023.

11. Sugaya T, Kawanami M, Kato H. Effects of debridement with an ultrasonic furcation tip in degree II furcation involvement of mandibular molars. J Int Acad Periodontol. 2002 Oct;4(4):138-42. PMid:12670094.

12. Solís Moreno C, Santos A, Nart J, Levi P, Velásquez A, Sanz Moliner J. Evaluation of root surface microtopography following the use of four instrumentation systems by confocal microscopy and scanning electron microscopy: an in vitro study. J Periodontal Res. 2012 Oct;47(5):608-15. http://dx.doi.org/10.1111/j.1600-0765.2012.01473.x. PMid:22494068.

13. Arora S, Lamba AK, Faraz F, Tandon S, Ahad A. Evaluation of the effects of Er,Cr: YSGG laser, ultrasonic scaler and curette on root surface profile using surface analyser and scanning electron microscope: an in vitro study. J Lasers Med Sci. 2016;7(4):243-9. http://dx.doi.org/10.15171/jlms.2016.43. PMid:28491260.

14. Rüdiger SG, Dahlén G, Carlén A. Protein and bacteria binding to exposed root surfaces and the adjacent enamel surfaces in vivo. Swed Dent J. 2015;39(1):11-22. PMid:26529838.

15. Talebi-Ardakani MR, Torshabi M, Karami E, Vajar N, Rezaei Esfahrood Z, Meimandi M, et al. Comparison of Er: YAG laser and hand instrumentation on the attachment of cultured human gingival fibroblasts to periodontally involved root surfaces. J Lasers Med Sci. 2017;8(Suppl 1):S51-5. http://dx.doi.org/10.15171/jlms.2017.s10. PMid:29071036.

16. Kocher T, Langenbeck N, Rosin M, Bernhardt O. Methodology of three-dimensional determination of root surface roughness. J Periodontal Res. 2002 Apr;37(2):125-31. http://dx.doi.org/10.1034/j.16000765.2002.00341.x. PMid:12009182.

17. Yurdaguven H, Aykor A, Ozel E, Sabuncu H, Soyman M. Influence of a prophylaxis paste on surface roughness of different composites, porcelain, enamel and dentin surfaces. Eur J Dent. 2012 Jan;6(1):18. PMid:22229001.

18. Souza BM, Comar LP, Vertuan M, Fernandes C No, Buzalaf MA, Magalhães AC. Effect of an experimental paste with hydroxyapatite nanoparticles and fluoride on dental demineralisation and remineralisation in situ. Caries Res. 2015;49(5):499-507. http://dx.doi.org/10.1159/000438466. PMid:26278685.

19. Lin X, Xie F, Ma X, Hao Y, Qin H, Long J. Fabrication and characterization of dendrimer-functionalized nano-hydroxyapatite and its application in dentin tubule occlusion. J Biomater Sci Polym Ed. 2017 Jun;28(9):846-63. http://dx.doi.org/10.1080/09205063.2017.1308654. PMid:28325103.

20. Meyer K, Lie T. Root surface roughness in response to periodontal instrumentation studied by combined use of microroughness measurements and scanning electron microscopy. J Clin Periodontol. 1977 May;4(2):77-91. http://dx.doi.org/10.1111/j.1600-051X.1977.tb01887.x. PMid:266507.

21. Meissner G, Oehme B, Strackeljan J, Kocher T. Influence of handling-relevant factors on the behaviour of a novel calculus-detection device. J Clin Periodontol. 2005 Mar;32(3):323-8. http://dx.doi.org/10.1111/j.1600-051X.2005.00679.x. PMid:15766378.

22. de Oliveira GJ, Cominotte MA, Beraldo TP, Sampaio JE, Marcantonio RA. A microscopic analysis of the effects of root surface scaling with different power parameters of er,cr:YSGG laser. Microsc Res Tech. 2015 Jun;78(6):529-35. http://dx.doi.org/10.1002/jemt.22505. PMid:25951453.

23. Preis V, Hahnel S, Behr M, Rosentritt M. Contact wear of artificial denture teeth. J Prosthodont Res. 2018 Apr;62(2):252-7. http://dx.doi.org/10.1016/j.jpor.2017.11.001. PMid:29217274.

24. Dahiya P, Kamal R. Ultra-morphology of root surface subsequent to periodontal instrumentation: A scanning electron microscope study. J Indian Soc Periodontol. 2012 Jan;16(1):96-100. http://dx.doi.org/10.4103/0972-124X.94613. PMid:22628971. 
25. Bozbay E, Dominici F, Gokbuget AY, Cintan S, Guida L, Aydin MS, et al. Preservation of root cementum: a comparative evaluation of power-driven versus hand instruments. Int J Dent Hyg. 2018 May;16(2):202-9. http://dx.doi.org/10.1111/idh.12249. PMid:27860247.

\section{CONFLICTS OF INTERESTS}

The authors declare no conflicts of interest.

\section{${ }^{*}$ CORRESPONDING AUTHOR}

Priscilla Barbosa Ferreira Soares, UFU - Universidade Federal de Uberlândia, Faculdade de Odontologia, Av. Pará, 1720, Bloco 4L, Anexo A, Campus Umuarama, 38400-902 Uberlândia - MG, Brasil, e-mail: pbfsoares@ufu.br

Received: April 9, 2019

Accepted: July 11, 2019 